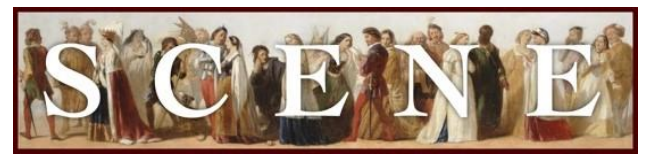

\title{
A Youthful Julius Caesar Experiment
}

\author{
by Erin E. Kelly and Janelle Jenstad. Published in 2019 Issue 1.
}

For the production: Julius Caesar(2019, Greater Victoria Shakespeare Festival). Performances attended: 2019-07O6 (Jenstad) and 2019-07-27 (Kelly). See production details at the end of the review.

The Greater Victoria Shakespeare Festival's 2019 Julius CaEsar included many of the elements now commonplace in professional productions of this play: mixed-gender casting, modern dress, and complex character portrayals that alternately invite and deflect audience sympathy. Such production choices seem ambitious given that this community-based company presents outdoor summer Shakespeare of the sort to which people bring children, dogs, and picnics. GVSF cannot count on an audience looking to be challenged or disturbed, but this group has been around long enough to take some risks. Because this production is the first GVSF offering to be reviewed for Scene, we describe the performance setting and the normal practices of the GVSF before we launch into our description and analysis of Julius Caesar, the most successful aspects of which were shaped by the landscape in which GVSF stages Shakespeare and by its habitual practice of casting young actors.

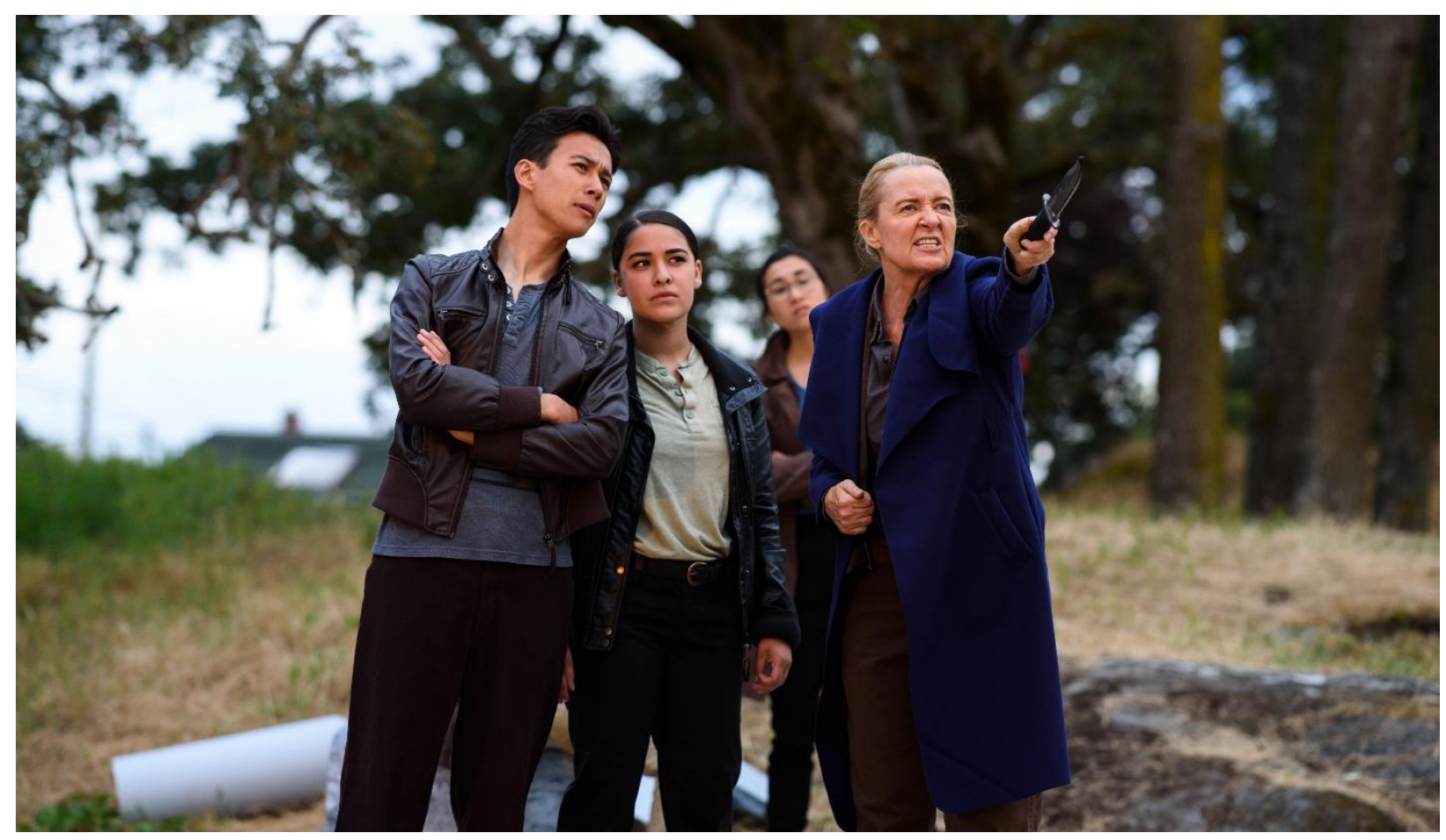

Figure 1. Douglas Peerless (Decius Brutus), Lara Hamburg (Cinna), Hilary Wheeler (Octavius), and Wendy Magahay (Casca) on the Camas Stage. Photo credit: Lara Eichhorn. 
The Greater Victoria Shakespeare Festival, which was scheduled to offer its thirtieth season of productions in 2020, has staged two productions in repertory every July since 2005 on the grounds of Camosun College in Victoria, the capital city of British Columbia, Canada, located at the southern tip of Vancouver Island. After a brief experiment of staging in the round under the protection of the roof of the Na'tsa'maht Indigenous Gathering Place, the festival moved its performance space eastward to an open lawn sloping gently southeast down towards a rocky outcropping that faces roughly northwest. On and in front of these glacier-scraped rocks sits the "Camas Stage," a "semi-modular semi-permanent" wooden frame named after a local blueflowering edible bulb, "in recognition of both the First Nations land on which it sits, and Shakespeare's original stage, The Rose" ("History"). The Camas plant (Camassia quamash) has been cultivated as a food crop for thousands of years by the Lekwungen peoples in meadows under the canopy of towering Garry oak trees (Quercus garryana, known as Oregon or white oaks to our American neighbours). A stand of these oaks rises out of the meadow, providing a natural backdrop that gradually blackens as the evening closes in. These trees are perfectly adapted for the drought climate we experience in July and August, a climate that means performances are almost never cancelled for weather events. These oaks invest their limited water supply in just a few large branches, which gives them a twisting open structure that contributes to the mood of GVSF productions. A smaller outcropping rises just beside the "house right" seating area. GVSF productions use this rock as a secondary staging area; it has served in past shows as a boat, a hiding spot, Puck's observation platform, the witches' meeting place in Macbeth, a musicians' gallery, and a platform for orations.

The playing area - and movement in and out of the playing area — is determined by what this iconic Garry oak meadow landscape affords. The larger rock rises to a smooth, flat, grass-covered area a few feet above the stage. This flat area generally serves for interior scenes; exits into imagined interior spaces see actors going up and over the rock, disappearing over the top of the rock and down into the barely concealed meadow that serves as a backstage area. To enter from stage left or stage right, actors walk around these trees, becoming visible to playgoers about fifty feet from the stage. These extraordinarily long entrances present challenges for the director but also offer opportunities to expand the spatial sense of action, especially of ceremonial arrivals and military assaults. Actors also move up and down the central and side aisles between the chalked-off seating areas, entering from a nearby classroom building where the actors change before and after the show. To the southwest of the trees and visible to house right, a historic home known as Dunlop House - atop another, still higher rock - provides a screen between the playing space and the nearby road; it also provides an acoustic wall that bounces sound back into the seating area, and a backdrop for the many talented musicians in the GVSF company, who 
generally stand far back by the trees to provide original musical arrangements and unobtrusive sound effects.

Set pieces are necessarily minimal, given that they must be carried in by actors and thus remain visible for the entire long walk to the stage. GVSF productions therefore tend to rely on small hand-props, minimal furniture, and the occasional suggestive bit of set dressing (such as a drape, a shrub, or a clothesline). During matinee performances, the stage is shielded from the full sun by a white, four-poster canopy. Performances compete with passing traffic and birds during the day, and with bats, mosquitos, and deer in the evening; the show stops only for deer, however, for which the company has developed wildlife safety protocols. Evening shows begin in the warm northern light of July summer evenings, which shines directly on the northwest-facing stage, and end in the chilly darkness that characterizes Victoria's ocean location. Locals know to bundle up; for those who come less prepared, GVSF supplies wool blankets and cushions, which playgoers collect from boxes beside a winding path as they walk into the performance space from the nearby parking lot to the west. As the natural evening light fades, two lighting trusses in the house left and house right take over the work of illumination. Against the darkening sky, the huge limbs of the oaks catch the artificial lighting and seem to loom out of the darkness, encircling and dwarfing the actors for the second half of the play.

GVSF is much loved by locals, some of whom attend annually as families and develop traditions of either sitting on blankets or bringing their own folding chairs. GVSF partners with local restaurants to offer picnic suppers. UVic Shakespeare instructors (the present writers included) give pre-show talks, or local musicians offer musical entertainment before the show. GVSF has undertaken an educational role in the community, both with its school Shakespeare program in November each year and with its "Young Company" initiative, in which emerging teenage theatre practitioners have a chance to hone their acting and musical skills. Between the setting among our iconic native trees, the territorial acknowledgement that precedes each performance, and the community partnerships, GVSF is very much a fixture in the Victoria landscape. We therefore approach any performance with a deep appreciation of the value of GVSF to our community, and with a sympathetic understanding of the limitations under which this company operates.

In this production of Julius Caesar, some of the creative responses to constraints were more successful than others. The open space, the youthful performers, and the small budget influenced the choices this production could make, but most notably what made this a less-than-effective (but nevertheless interesting) production was the cast. Despite being a regular offering on the high school curriculum, Julius Caesar is not a young person's play. The play's main characters, who agonize over their posthumous reputation, need to have a certain gravitas. 
So, what happens when you stage this mature play with a very young cast? GVSF offered a possible answer by performing Julius Caesarwith what it described as its "largest junior company yet" ("Introducing"). Seven of the thirty members of its cast (performing Julius Caesar and Two Gentlemen of Verona in repertory) were between the ages of thirteen and eighteen, apprentice actors receiving training while taking on small roles. Some other performers in this company were not much older, with several still in university programs and others only recently graduated. The youthful energy of the company problematically skewed some aspects of the play, but made others unexpectedly compelling.

Quite often a production of Julius Caesar will invite us to empathize with at least one of three main characters: Brutus, Caesar, or Antony. Of the three in this production, Brutus (Jack Hayes) was the most complexly rendered, but our sympathies never entirely coalesced around any of these figures. By casting one of the most mature members of the cast as Caesar (James McAndrew), the director (Tamara McCarthy) created the potential for an interesting sense of generational tension; through such casting, the director might have suggested that the conspirators were seeking to seize political authority from a man who had aged out of his power. The largely modern-dress costuming would certainly have supported such a possibility. Caesar was wearing a stiff, militaristic suit blazer with brass buttons, while Brutus and the conspirators wore their leather jackets casually unzippered. The sartorial contrast was most obvious in the assassination scene, when the leather-clad conspirators surrounded Caesar's more formally attired corpse.

Yet this potential for intergenerational tension was not fully realized, and the youth of the conspirators created problems in the second half of the play. While Brutus did seem the most thoughtful character among the major roles, it was difficult to tell why others looked to him for leadership initially and then turned against him. He continued to wear his leather jacket throughout the production; at the very least, a costume change that aligned him with the earlier style of Caesar might have suggested why some supporters and fellow conspirators came to be dubious of Brutus's trustworthiness or chances at victory.

Again, however, we have to remember that this production boasted the largest GVSF young company to date - a company required for the other play in the summer repertory, Two Gentlemen of Verona. When not serving as Brutus, Hayes played a brilliant Proteus on alternate nights, which ought to suggest to readers both the relative youth of this Brutus and the challenge facing this actor in the 2019 season.

The fact that Cassius was played by young female actor Stephie Bright (in keeping with GVSF's now regular and quietly unremarkable practice of gender-blind casting) isn't what made it seem unlikely that he and the much older, male Caesar had gone to school together; rather, Bright's 
performance made it difficult to tell why this character would ever imagine himself equal to Caesar. The relatively one-note presentation of this shouty Cassius was perhaps made more problematic by the actor's vocal problems; the hoarseness Kelly noticed on the final night of the run was also apparent when Jenstad attended an earlier performance, and this vocal quality suggested that the actor was struggling to project loudly enough to be heard in the open-air outdoor performance space.

Angela Kostiniuk's rendition of Antony's speech ironically praising Brutus as "an honorable man" fell flat because it seemed more a recitation than a set of arguments he was discovering in real time under pressure. And the necessary reliance on young cast members created a problem for the play's representation of Octavius (played by Hilary Wheeler). Often Octavius is played by the youngest member of a cast so that he will seem an upstart in relation to Antony, not to mention in comparison to the battle-hardened conspirators. When Octavius appears to be no more jejune than most of the other Romans, it becomes difficult to understand why no one takes him seriously. Octavius, usually the only young person in a production of the play, should seem outmatched and outclassed, but here he didn't seem that different from Antony or Cassius.

But there were moments when the large cast and its many young members added a great deal of other interest. The crowd scenes were unusually affecting, as clusters of those acting as the audience for speeches by Brutus and then Antony seemed in turn confused and then all-tooeasily led. In an era of "fake news," it was powerful to witness varied performances of how an individual might react to waves of conflicting messages that could not be easily verified. The encounter of a group of plebeians with Cinna the Poet was particularly disturbing as the young Antony-supporters recalled a teenaged gang, not quite sure of what it was doing but capable of inflicting horrific damage.

The fearless physicality of the young actors made possible visually striking battle scenes. Although performers necessarily used the sprawling grounds around the small platform stage for exits and entrances, most dialogue and action took place on the raised platform - until the battles at Philippi. At this point in the play, fighting metastasized across the landscape as actors chased one another under Garry oaks and over granite outcroppings to throw their enemies onto ragged grass. The vicious fighting conveyed both urgency and danger, and the expansion beyond the platform stage symbolized how what had been the discontent of a small group of conspirators eventually reached far beyond the Capitol to spread chaos across the Roman empire.

Another memorable moment in the production offered a very different rendering of violence. The assassination of Caesar can be staged as a bloody affair, but here it was more abstract. After the conspirators stabbed Caesar with daggers, each one pulled from the corpse's torso a long red silk streamer symbolizing blood. Once the ruler was pronounced dead, the actor playing Caesar 
rose, already ghostly, and walked solemnly offstage, leaving the conspirators to gather around a powerfully significant absence. (Unfortunately, the representational power of this scene was undermined by inexplicable realism when Brutus entered later to deliver his justification of the assassination with stage blood dripping from his hands.)

Negative space became similarly meaningful in the scene in which Brutus tells Cassius about Portia's death. Retreat into a private space (something that is always a challenge in this large open-air setting) was signified by two simple canvas triangles upstage right that visually signified the entrance to a tent. Once they moved through these suggested tent flaps, Brutus and Cassius began to speak freely. The fragility of the quiet exchange between the two characters and the vulnerability of each character - seemed perfectly visualized by the use of nothing more than two bits of cloth as a shelter. Despite being heavily pruned, this scene gave a better sense of the conflict between Cassius and Brutus than was portrayed in earlier exchanges between the conspirators and Caesar. We felt the inevitability of fragmentation within the conspiracy come to fruition in this moment.

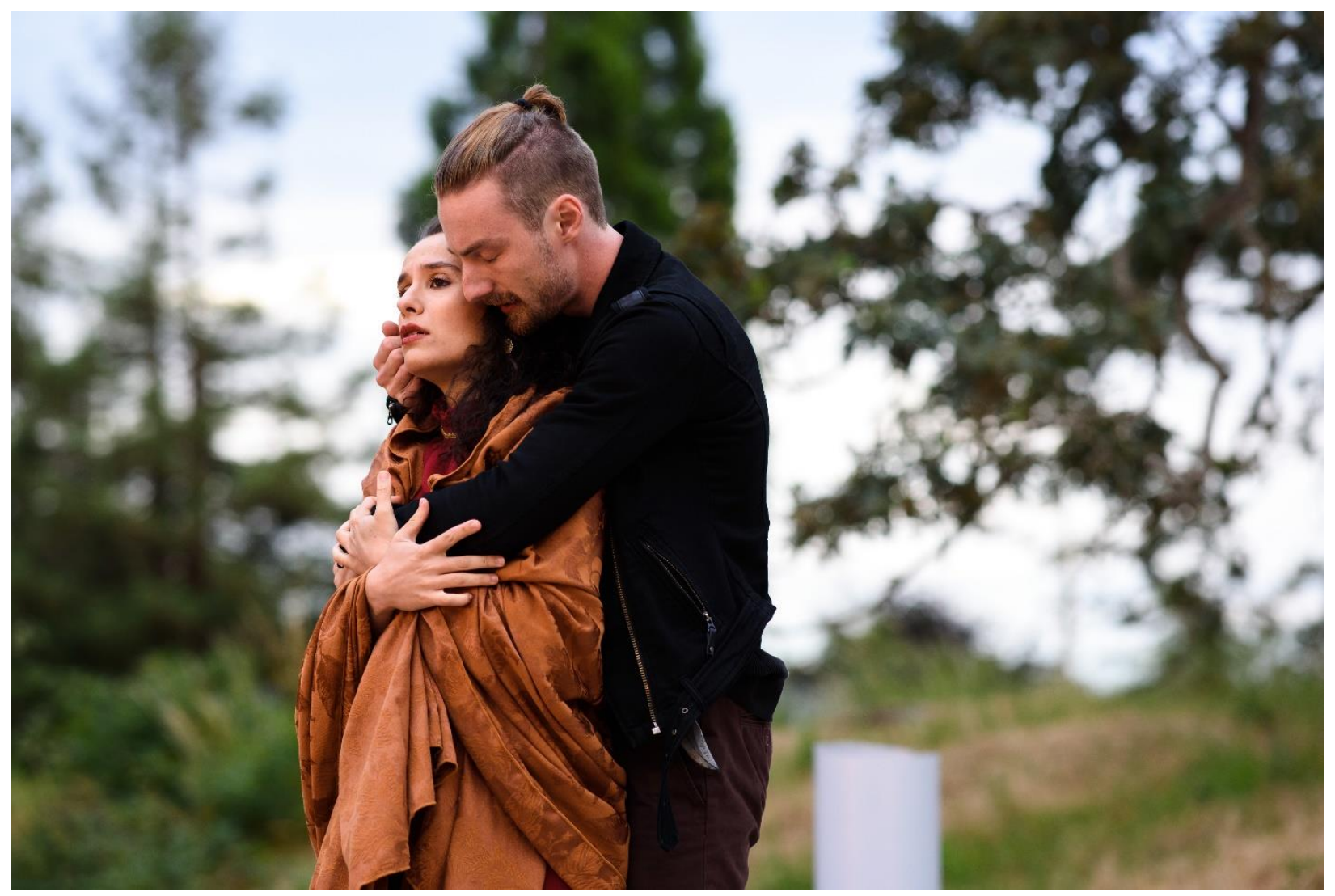

Figure 2. Isabella Giampaolo (Portia) and Jack Hayes (Marcus Brutus). Photo credit: Lara Eichhorn.

In other words, this production made some strong choices that created interesting effects. Aspects of the performances we witnessed that didn't work often seemed the result of a failure 
to make thoughtful decisions. For instance, we were both puzzled by the presentation of Portia. Was Brutus's wife dressed in the scarlet stola of a Roman matron because actors playing Portia typically appear in Roman dress? Certainly, this costume seemed out of place with the modern dress worn by all other performers; it might charitably be read as a visual nod to the director's decision to "set in the now, $44 \mathrm{BC}$, and all time between" (McCarthy 10), but we agreed that it seemed as if Portia had wandered in from another production. And why have so many of the Romans costumed in fatigues or khaki jackets with brass buttons - strong nods in the direction of military uniforms - if they were going to stand, move, and fight in such unruly, undisciplined ways? Perhaps designer Michelle Mitchell thought a battle scene means military attire is necessary?

This unusual production, as both reviewers concur, could not escape its experimental status. While youthful enthusiasm can lead to compelling theatre, in this instance incongruous design and directorial choices, like the open-air outdoor performance space in which it was staged, added to the difficulties that the less experienced actors worked hard, with limited success, to overcome.

\section{References}

"History." Greater Victoria Shakespeare Festival. 2015. http://www.vicshakespeare.com/history. “Introducing ... Our Largest Junior Company Yet!” Shakesblog by the Greater Victoria

Shakespeare Festival. July 10, 2019.

http://www.vicshakespeare.com/blog/2019/7/2/introducing-our-largest-junior-company-yet. McCarthy, Tamara. “Julius Caesar-Director's Notes.” Greater Victoria Shakespeare Festival Season Program, 2019. p. 10.

\section{Links}

Greater Victoria Shakespeare Festival. http://www.vicshakespeare.com/. Na'tsa'maht Indigenous Gathering Place. http://camosun.ca/learn/school/indigenouseducation-community-connections/about/natsamaht.html. 


\section{Production Details}

\section{General}

\section{Title}

Year

Theatre Company

Start Date

End Date

\section{Julius Caesar}

2019

Greater Victoria Shakespeare Festival 2019-07-04

2019-07-27

\section{Cast}

\begin{tabular}{|c|c|}
\hline CALPURNIA/SOLDIER & NICOLE BARTOSINSKI \\
\hline CASsius & STEPHIE BRIGHT \\
\hline PINDARUS/THIRD CitIZEN & SIVERT DAS \\
\hline PORTIA/LEPIDUS & ISABELLA GIAMPAOLO \\
\hline COBBLER/LUCIUS/CATO/MUSICIAN & HOLLY COLLIS HANDFORD \\
\hline CINNA/FifTH CitIZEN/SOLDIER & LARA HAMBURG \\
\hline MARCUS BRUTUS & JACK HAYES \\
\hline SERVANT TO OCTAVIUS/VARRO/CITIZEN & ASA O'CONNOR-JAECKEL \\
\hline MARK ANTONY & ANGELA KOSTINIUK \\
\hline Metellus Cimber/Cinna The & TAYLOR LEWIS \\
\hline \multicolumn{2}{|l|}{ POET/TITINIUS/CARPENTER } \\
\hline SERVANT TO CAESAR/CLAUdiUS/CITIZEN & ALEXANDER LINDHOLM \\
\hline CASCA/Flavius/Clitus & WENDY MAGAHAY \\
\hline SENATOR/SECOND CITIZEN & ERRIN PORTER MCANDREW \\
\hline JULIUS CAESAR & JAMES MCANDREW \\
\hline MESSENGER/SERVANT TO & JULIE MCGUIRE \\
\hline \multicolumn{2}{|l|}{ ANTONY/MUSICIAN/SOLDIER/CITIZEN } \\
\hline VOLUMNIUS/CITIZEN/MUSICIAN & ELI MORROW \\
\hline DECIUS BRUTUS/LUCILIUS & DOUglas PEERLESS \\
\hline MARULLUS/MESSALA & AARON SMAIL \\
\hline SOOTHSAYER/FOURTH CITIZEN/STRATO/MUSICIAN & MATTHEW WHEADON \\
\hline OCTAVIUS/FIRST CITIZEN/MUSICIAN & HILARY WHEELER \\
\hline TREBONIUS/SOLDIER & OLIVIA WHEELER \\
\hline
\end{tabular}

\section{Creatives}

DIRECTOR

COSTUMER
TAMARA MCCARTHY

MiCHELLE MitCHELL 


\author{
Costume Assistant \\ MUSIC DiRECTOR/COMPOSER \\ MOVEMENT DIRECTOR \\ STAGE MANAGER \\ Assistant Stage MANager \\ PRODUCTION COORDINATOR
}

\begin{abstract}
NICOLE FAUCHER
\end{abstract}
OLIVIA WHEELER

NICOLE BARTOSINSKI

AVRY PAYNE

EMILY WiLLCOX

BRIAN QUAKENBUSH 